\title{
Does Reputation Talk? The Matching of Underwriters and Issuing Firms
}

\author{
McKenzie, C. R. ${ }^{a}$ and Sumiko Takaoka ${ }^{\mathrm{b}}$ \\ ${ }^{a}$ Faculty of Economics, Keio University, Tokyo, JAPAN \\ ${ }^{\mathrm{b}}$ Faculty of Economics, Seikei University, Tokyo, JAPAN \\ Email: takaoka@econ.seikei.ac.jp
}

\begin{abstract}
The purpose of this paper is to examine the role of reputation in the matching of underwriters and issuing firms in the straight corporate bond market in Japan. While the existing literature already investigates how the issuing firm chooses its underwriter at the time of issue, this paper uses initial and seasoned issues of straight corporate bonds to examine how the matching of underwriters and issuing firms changes over time.

Data on individual issues of straight corporate bonds publicly issued in Japan between 25 February 1994 and 31 December 2009 are used to estimate models which explain how issuing firms match with underwriters. We measure the reputations of underwriters and issuing firms using each underwriter's percentile rank in the underwriting market and the issuer's percentile rank in the issuing proceeds, respectively. Changes in the rating of the issuing firm's bonds are also used to measure reputation changes. Since the measures of reputation are computed for each individual bond issue, it is possible to compute how reputation changes over time.

Much of the existing literature on underwriter choice focuses on how underwriter choices change between the initial public offering (IPO) and seasoned equity offering (SEO). We construct a data set of straight corporate bond issues which includes many repeated issues. One of the contributions in this paper is to take account of these repeated issues by treating the data as a panel data set, and allowing for an issuer random effect. This random effect is found to be significant.

The estimation results show that issuing firms match with the same underwriter when the difference of the issuer's reputation and the current reputation of the previous underwriter is small. Issuing firms with an AAA rating at the time of issue are less likely to match with the same underwriters. In addition to reputation effects, there is strong evidence to suggest that issuing firms continue to stay matched with the same underwriter if the underwriter is a subsidiary of the issuing firm's main bank.
\end{abstract}

Keywords: Corporate bonds, Japan, matching, reputation, underwriter 


\section{INTRODUCTION}

The importance of reputation in capital markets has been repeatedly emphasized. For issues of securities, it is not only the reputation of the firm which issues the equity or bond that is important, but also the reputation of the underwriter which the firm employs for the securities offering that is believed to be important. This paper examines how the reputations of both the issuing firm and underwriters affect the decisions of Japanese firms over time when the firm chooses an underwriter for its issues of straight bonds.

The choice of underwriter has been analyzed mainly for issues in the equity market (for example, Titman and Trueman (1986), Habib and Ljungqvist (2001), and Burch et al. (2005)). The problem of how the issuing firm and underwriter for equity offerings match between IPO and SEOs issues has also been examined (see Fernando et al. (2005). Legros and Newman (2002) contains a more detailed discussion of matching theory). Fernando et al. (2005) develop a model based on matching theory to explain the mutual choices made by issuing firms and underwriters, and find strong evidence that higher quality issuing firms associate with higher ability underwriters, and lower quality issuing firms associate with lower ability underwriters.

Some existing research on an issuing firm's choice of underwriter for straight corporate bond issues focuses on the choice of the underwriter type. For example, Hamao and Hoshi (2000) analyze whether or not the issuing firms have a propensity to choose the underwriter which is a bank subsidiary, and whether the underwriter is a main bank subsidiary or not (Hamao and Hoshi (2004)). Yasuda (2005) investigates which particular underwriter is chosen as the issuing firm's underwriter. While these papers consider the static analysis of underwriter choice at the time of an issue, McKenzie and Takaoka (2005) examine the switching of underwriters between the initial public issue of a corporate bond and the second public issue of a corporate bond.

Much of the existing literature on underwriter choice focuses on how underwriter choices change between the initial public offering (IPO) and seasoned equity offerings (SEOs). Here, every straight bond issue made by a firm over a 15 year period is included in the analysis, so the data set includes many repeated issues. One of the contributions in this paper is to take account of these repeated issues by treating the data as a panel data set, and allowing for an issuer random effect. This random effect is found to be highly significant.

While we confirm the results reported in Fernando et al. (2005) relating to reputation effects, not all the matching in our data set can be explained by transaction base matching which implies that issuers and underwriters rematch only when firm characteristics and underwriter abilities are stable over time. When an issuer matches with an underwriter that is a subsidiary of the issuer's main bank, there is a significant tendency to rematch with the same underwriter even after considering the reputation effects of the issuing firm and the underwriter.

The remainder of the paper proceeds as follows. Section 2 discusses the hypotheses to be tested. Section 3 describes the model to be estimated. Details of the data used in this analysis are explained in section 4. Descriptive statistics and the results of estimating probit models to explain the switching of underwriters are discussed in section 5. Section 6 presents a short conclusion.

\section{HYPOTHESES}

In explaining whether or not an issuing firm switches its underwriter, there are six potential hypotheses that have been suggested in the literature. The first hypothesis relies on matching theory, and argues that changes in the reputation of underwriters and the issuing firm between issues will lead the issuing firm to change its underwriter (see Fernando et al. (2005)). Fernando et al. (2005) argue that if the reputation of an issuer improves sufficiently after the most recent past security issue, then the issuer will switch to a higher quality underwriter. Similarly, if the quality of the underwriter chosen for the most recent past security issue improves sufficiently, then the issuer will switch to a lower quality underwriter. In contrast to this transaction based matching which emphasises the current reputations of the underwriter and issuer, the second hypothesis emphasizes the existing relationship between an issuing firm and its main bank. There are several possible ways that the existence of a main bank might influence an issuing firm's choice 
of underwriter. In the course of its continuing relationship with the issuing firm, a main bank is likely to accumulate private information on the issuing firm which might be useful when the issuing firm wishes to issue a new security. Alternatively, a main bank may be able to apply pressure on the issuing firm to choose the main bank's securities subsidiary as the lead underwriter (for anecdotal evidence see Takaoka and McKenzie (2006)). The third hypothesis is Krigman et al. (2001)'s graduation effect hypothesis that predicts that between IPO and SEO issues issuing firms will tend to switch underwriters when they can obtain the services of an underwriter with a better reputation for the follow-on offering.

Assuming that the private information an underwriter obtains in the course of underwriting a bond issue depreciates over time, the fourth hypothesis suggests that as the time between successive issues increases, the probability of switching also increases. A fifth hypothesis suggests that the underwriter's past performance (for example, the size of mispricing) for the most recent issue will affect the likelihood of that underwriter being chosen again. Finally, issuing firms may seek to avoid the lock-in effects that result from repeatedly using the same underwriter.

The analysis in this paper focuses on investigating the extent to which the first three hypotheses can explain the observed underwriter outcomes in the Japanese straight bond market.

\section{MODEL}

The following model is assumed to explain the switching of the lead underwriter that is used by an issuing firm for the current bond issue and the most recent prior bond issue:

$$
S W I T C H_{i, j}^{*}=a+b^{\prime} X_{i, j}+e_{i, j}+u_{i},
$$

where $S W I T C H_{i, j}^{*}$ is a latent variable which could be interpreted as being the difference in the net benefits of a bond issued by issuer $i$ when a different lead underwriter is used for the $j$ th issue compared to using the same lead underwriter as was used for the $j-1$ th issue, $X_{i, j}$ is a vector of explanatory variables related to the $j$ th issue by the $i$ th issuer, $b$ is a vector of unknown parameters, $e_{i, j}$ is a random variable which is assumed to be distributed according to a normal distribution with variance $\sigma_{e}^{2}$, and $u_{i} \sim N\left(0, \sigma_{u}^{2}\right)$. The disturbance $u_{i}$ generates issuer random effects. Defining $\rho$ as $\rho=\sigma_{u}^{2} /\left(\sigma_{u}^{2}+\sigma_{e}^{2}\right)$ means it is possible to test for the presence/absence of issuer random effects by testing the null hypothesis $H_{0}: \rho=0$. It is assumed that

$$
S W I T C H_{i, j}= \begin{cases}1 & S W I T C H_{i, j}^{*} \geq 0 \\ 0 & S W I T C H_{i, j}^{*}<0\end{cases}
$$

where $S W I T C H_{i, j}$ is an observable variable taking the value unity if different lead underwriters are used by the $i$ th issuer for the $j$ th issue and $j$ - $l$ th issue, and zero otherwise ${ }^{1}$. In the existing literature, when $S W I T C H_{i, j}=1(=0)$ the issuing firm is referred to as a switcher (stayer). The combination of (1) and (2) means that a random effects probit model can be used to explain variations in $S W I T C H_{i, j}{ }^{2}$.

The variables used in $X_{i, j}$ are defined as follows. An underwriter's reputation in year $\mathrm{t}$ is computed as the underwriter's percentile rank of the total amount of straight bond issues it underwrote in the three year period $(\mathrm{t}-2, \mathrm{t}-1, \mathrm{t})$. The variable Current reputation of the previous underwriter is the reputation of the underwriter used by firm $i$ for issue $j-1$ measured for the year in which the $j$ th issue was made. Change in reputation of the previous underwriter is the change in the reputation of the underwriter used by firm $i$ for

${ }^{1} S W I T C H_{i, j}$ is only defined when it is physically possible for the $i$ th issuer to choose as the lead underwriter of the $j$ th issue the lead underwriter chosen for the $j$ - 1 th issue.

${ }^{2}$ As noted in McKenzie and Takaoka (2005), there are numerous cases of an issuer making multiple issues on the same day, that is, issuing several bonds of different maturities on the same day. For the purpose of defining $S W I T C H_{i, j}$, these multiple issues were dealt with as follows. Suppose the current issue is a single issue, and the most recent prior issue is a multiple issue. In this case, a switch is deemed to have occurred if the lead underwriter for the current issue differs from all the lead underwriters associated with the multiple issue. Suppose the current issue is a multiple issue, and the most recent prior issue is a single issue. Each of the maturities in the multiple issue is treated separately. If the lead underwriter for one of the maturities is the same as the lead underwriter for the single issue, a switch is deemed not to have occurred for the bond with that maturity. Suppose the current issue is a multiple issue, and the most recent prior issue is a multiple issue. Each of the maturities in the current multiple issue is treated separately. If the lead underwriter for one of the maturities of the current multiple issue is the same as the lead underwriter for any one of the issues in the previous multiple issue, a switch is deemed not to have occurred for that current issue. 
issue $j-l$ between the years in which the $j$ th issue and the $j$ - $l$ th issue were made. Using information on the total amount of straight bonds issued in any year by a given firm, the firm's reputation in a given year is computed as its percentile ranking. The variable Difference of the issuer's reputation and the current reputation of the previous underwriter is defined as the difference between the issuing firm's reputation for the year in which the $j$ th issue was made and the reputation of the underwriter used by firm $i$ for issue $j-1$ measured for the year in which the $j$ th issue was made. Main Bank $U W$ dummy is a 0-1 dummy variable taking the value one if the lead underwriter for the $j$ - $l$ th issue by firm $i$ is a subsidiary of the firm's main bank, and zero otherwise. A firm's main bank is defined as the private financial institution (excluding insurance companies) with the largest shareholding in the issuing firm. A firm is deemed not to have a main bank if there are no private financial institutions (excluding insurance companies) in the list of top shareholders. The original long-term ratings data for the issuing firm is of the form AAA, AA+, $\mathrm{AA}, \mathrm{AA}-, \mathrm{A}+, \mathrm{A}, \mathrm{A}-, \mathrm{BBB}+, \mathrm{BBB}$, and BBB-. AAA rating is a 0-1 dummy variable taking the value unity if the issuing firm's rating is AAA, and zero otherwise; AA rating is a 0-1 dummy variable taking the value unity if the issuing firm's rating is AA+, AA or AA-, and zero otherwise; A rating is a 0-1 dummy variable taking the value unity if the issuing firm's rating is $\mathrm{A}+, \mathrm{A}$ or $\mathrm{A}-$, and zero otherwise; and $B B B$ rating is a $0-1$ dummy variable taking the value unity if the issuing firm's rating is $\mathrm{BBB}+$, $\mathrm{BBB}$ or $\mathrm{BBB}-$, and zero otherwise. In the regression analysis, AAA rated bonds are used as the base group.

Each of the ratings is assigned a numerical value between one and ten, with AAA (BBB-) being assigned the lowest (highest) value one (ten). The variable $\Delta$ Rating is the difference between the numerical rating of the $j$ th issue and the $j$ - $l$ th issue. A positive value of $\Delta$ Rating means that the issuing firm's rating has worsened between the $j$ - $l$ th issue and the $j$ th issue.

Following Krigman et al. (2001), it is expected that an improvement in the Current reputation of the previous underwriter will reduce the probability of a switch, and a Change in the reputation of the previous underwriter will increase the probability of a switch. Following the arguments of Fernando et al. (2005), it is expected that an increase in the Difference of the issuer's reputation and the current reputation of the previous underwriter will increase the probability of a switch. The arguments in section 2 suggest that the coefficient on Main Bank UW dummy will be negative, so that using the main bank's securities subsidiary to underwrite the most recent past issue will increase the probability that the same underwriter is chosen the next time round.

\section{DATA}

The sample period used in this paper starts on February 25th, 1994, and ends on December 31st, 2009. The starting date is when the first bank subsidiary underwriting of a straight bond issue took place. The data set used in this paper is constructed from various data sources. Data on straight corporate bonds issued by individual firms are taken from the Thomson One Investment Banking database. This data set includes details of the lead underwriter ${ }^{3}$ and the underwriting syndicate for each bond issue in the sample period. Information about the relationship between the issuing firm and financial institutions comes from the Nikkei Corporate Quarterly (Nikkei Kaisha Joho). Over the course of the sample period, several new entries, mergers, acquisitions and bankruptcies occurred in both the securities and banking industries. Information about these mergers and acquisitions, new market entry and bankruptcies is collected from the Nikkei newspaper data base, Nikkei Telecom 21. We treat issues underwritten by merged or acquired securities firms as follows. For example, Tokyo Mitsubishi Securities acquired Mitsubishi Trust Securities on 1 July 1999. Tokyo Mitsubishi Securities is treated as the successor of Mitsubishi Trust Securities so that if a firm used Tokyo Mitsubishi Securities as the lead underwriter for its $j$ - 1 th bond issue, and Tokyo Mitsubishi Securities as the lead underwriter for its $j$ th bond issue, we do not consider this to be a switch of the lead underwriter. If instead, the firm chose Nomura Securities as the lead underwriter for the $j$ th bond issue, this choice would be counted as a change of the lead underwriter.

\footnotetext{
${ }^{3}$ There are of course issues when there is more than one lead underwriter. In these cases, we choose the lead underwriter that is listed in the Thomson database as the bookrunner as being the lead underwriter for the particular issue. The bookrunner is the underwriter that receives the issuing mandate from the issuer, and is consulted by the issuer regarding the timing, size and pricing of the issue, engages in ex ante marketing with investors, and sets the levels for demand forecasts.
} 


\section{Estimation Results}

Table 1 presents details of the descriptive statistics for all the variables used in the regression analysis for the full sample, and for when firms switch their underwriter $\left(S W I T C H_{i, j}=1\right)$ and stay with the same underwriter $\left(S W I T C H_{i, j}=0\right)$. In the fifteen year period being examined, $66 \%$ of firms switch their underwriters between issues. Firms whose previous bond issues were underwritten by a subsidiary of their main bank have a tendency to stay with the same underwriter.

Table 2 provides a cross tabulation of the rating of the firm at the time of an issue and whether the issuing firm rematches with the same underwriter or switches. Firms with an AAA rating have an extremely strong propensity to switch their underwriter.

In Table 3, the results of estimating equations (1) and (2) excluding and including the firm's current rating and the change in the issuer's rating between the current and previous issues are presented. Both of these models are also estimated with and without random issuer effects. Estimates of the marginal effects for each variable and their asymptotic t-values are also presented. All models were estimated using LIMDEP Version 9.0. The estimates of $\rho$ indicate the presence of significant random issuer effects.

The results in Table 3 provide support for both transaction base matching and relationship based matching. In all models presented in Table 3, the variable measuring the difference between issuer and underwriter reputations is highly significant with a positive estimated coefficient. Thus, an improvement in the issuer's reputation vis a vis the underwriter's reputation increases the probability of a switch. The main bank dummy is also consistently highly significant with a negative estimated coefficient. While the estimated coefficients of the variables associated with the graduation hypothesis variables are of the right sign, their statistical significance depends on the model being estimated. The evidence in favour of the graduation hypothesis is rather weak. Compared to bonds with AAA ratings, there is tendency for lower rated issues to have a lower probability of switching.

Table 1: Descriptive Statistics

\begin{tabular}{|c|c|c|c|c|c|c|}
\hline \multirow[b]{2}{*}{ Variable } & \multicolumn{2}{|c|}{ All } & \multicolumn{2}{|c|}{ Switch } & \multicolumn{2}{|c|}{ Stay } \\
\hline & Mean & Std Dev. & Mean & Std Dev. & Mean & Std Dev. \\
\hline Switch & 0.66 & 0.47 & 1 & 0 & 0 & 0 \\
\hline $\begin{array}{l}\text { Current reputation of } \\
\text { the previous underwriter }\end{array}$ & 0.83 & 0.16 & 0.82 & 0.18 & 0.85 & 0.13 \\
\hline $\begin{array}{l}\text { Change in reputation of the } \\
\text { previous underwriter }\end{array}$ & 0.004 & 0.07 & 0.004 & 0.07 & 0.004 & 0.08 \\
\hline $\begin{array}{l}\text { Difference of the issuer's reputation } \\
\text { and the current reputation of the } \\
\text { previous underwriter }\end{array}$ & -0.18 & 0.33 & -0.14 & 0.32 & -0.26 & 0.32 \\
\hline Main Bank UW dummy & 0.19 & 0.39 & 0.17 & 0.37 & 0.23 & 0.42 \\
\hline AAA rating & 0.15 & 0.35 & 0.20 & 0.40 & 0.05 & 0.21 \\
\hline AA rating & 0.36 & 0.48 & 0.34 & 0.48 & 0.38 & 0.49 \\
\hline A rating & 0.40 & 0.49 & 0.36 & 0.48 & 0.47 & 0.50 \\
\hline $\mathrm{BBB}$ rating & 0.10 & 0.30 & 0.10 & 0.29 & 0.10 & 0.30 \\
\hline$\Delta$ Rating & 0.05 & 0.60 & 0.04 & 0.48 & 0.07 & 0.78 \\
\hline Sample Size & \multicolumn{2}{|c|}{3,981} & \multicolumn{2}{|c|}{2,631} & \multicolumn{2}{|c|}{1,350} \\
\hline
\end{tabular}

\section{Conclusion}

This paper investigates the matching of underwriters and issuing firms over time using a sample of bond issues that contains many repeated bonds issue. The evidence presented supports both the presence of transaction based matching and relationship based matching. The reputations of both the issuing firm and the underwriter used for the most recent past issue influence whether or not switching of underwriters occurs. The probability of switching is reduced when an underwriter that is a subsidiary of the issuing firm's main bank is chosen for the most recent issue. 
Table 2: Issuer Ratings and Switching

\begin{tabular}{|c|c|c|c|c|c|c|c|}
\hline \multicolumn{4}{|c|}{ A: Cross frequency } & \multicolumn{4}{|c|}{ B: Row proportion } \\
\hline Rating & Stay & Switch & Total & Rating & Stay & Switch & Total \\
\hline AAA & 65 & 517 & 582 & AAA & 0.11 & 0.89 & 1 \\
\hline $\mathrm{AA}$ & 512 & 906 & 1,418 & AA & 0.36 & 0.64 & 1 \\
\hline A & 634 & 956 & 1,590 & $\mathrm{~A}$ & 0.40 & 0.60 & 1 \\
\hline BBB & 139 & 252 & 391 & $\mathrm{BBB}$ & 0.36 & 0.64 & 1 \\
\hline Total & 1,350 & 2,631 & 3,981 & Total & 0.34 & 0.66 & 1 \\
\hline
\end{tabular}

\section{ACKNOWLEDGMENTS}

Both authors gratefully acknowledge the financial assistance provided by the Japan Society for the Promotion of Science (JSPS) Grant in Aid for Scientific Research (B) No.21330079 for a project on "A Dynamic Analysis of Price Formation in Securities Markets".

\section{REFERENCES}

Burch, T., V. Nanda, and V. Warther (2005). Does it pay to be loyal? An empirical analysis of underwriting relationships an fees. Journal of Financial Economics 77(3), 673-699.

Fernando, C. S., V. A. Gatchev, and P. A. Spindt (2005). Wanna dance? How firms and underwriters choose each other. Journal of Finance 60(5), 2437-2469.

Habib, M. A. and A. Ljungqvist (2001). Underpricing and entrepreneurial wealth losses in IPOs: Theory and evidence. Review of Financial Studies 14, 433-458.

Hamao, Y. and T. Hoshi (2000). Bank-owned security subsidiaries in Japan: Evidence after the 1993 financial system reform. Oxford University Press, Oxford.

Hamao, Y. and T. Hoshi (2004). Bank underwriting of corporate bonds: Evidence from Japan after the financial system reform of 1993. Mimeo, University of California, San Diego.

Krigman, L., W. H. Shaw, and K. L. Womack (2001). Why do firms switch underwriters? Journal of Financial Economics 60, 245-284.

Legros, P. and A. F. Newman (2002). Monotone matching in perfect and imperfect worlds. Review of Economic Studies 69, 925-942.

McKenzie, C. R. and S. Takaoka (2005). Underwriter switching in the Japanese corporate bond market. In A. Zerger and R. Argent (Eds.), MODSIM 2005 International Congress on Modelling and Simulation, pp. 580-586.

Takaoka, S. and C. R. McKenzie (2006). The impact of bank entry in the Japanese corporate bond market. Journal of Banking and Finance 30, 59-83.

Titman, S. and B. Trueman (1986). Information quality and the valuation of new issues. Journal of Accounting and Economics 8, 159-172.

Veall, M. and K. Zimmermann (1996). Pseudo- $\mathrm{R}^{2}$ measures for some common limited dependent variable models. Journal of Economic Surveys 10(3), 241-259.

Yasuda, A. (2005). Do bank-firm relationships affect bank competition in the corporate bond underwriting market? Journal of Finance 60(3), 1259-1292. 


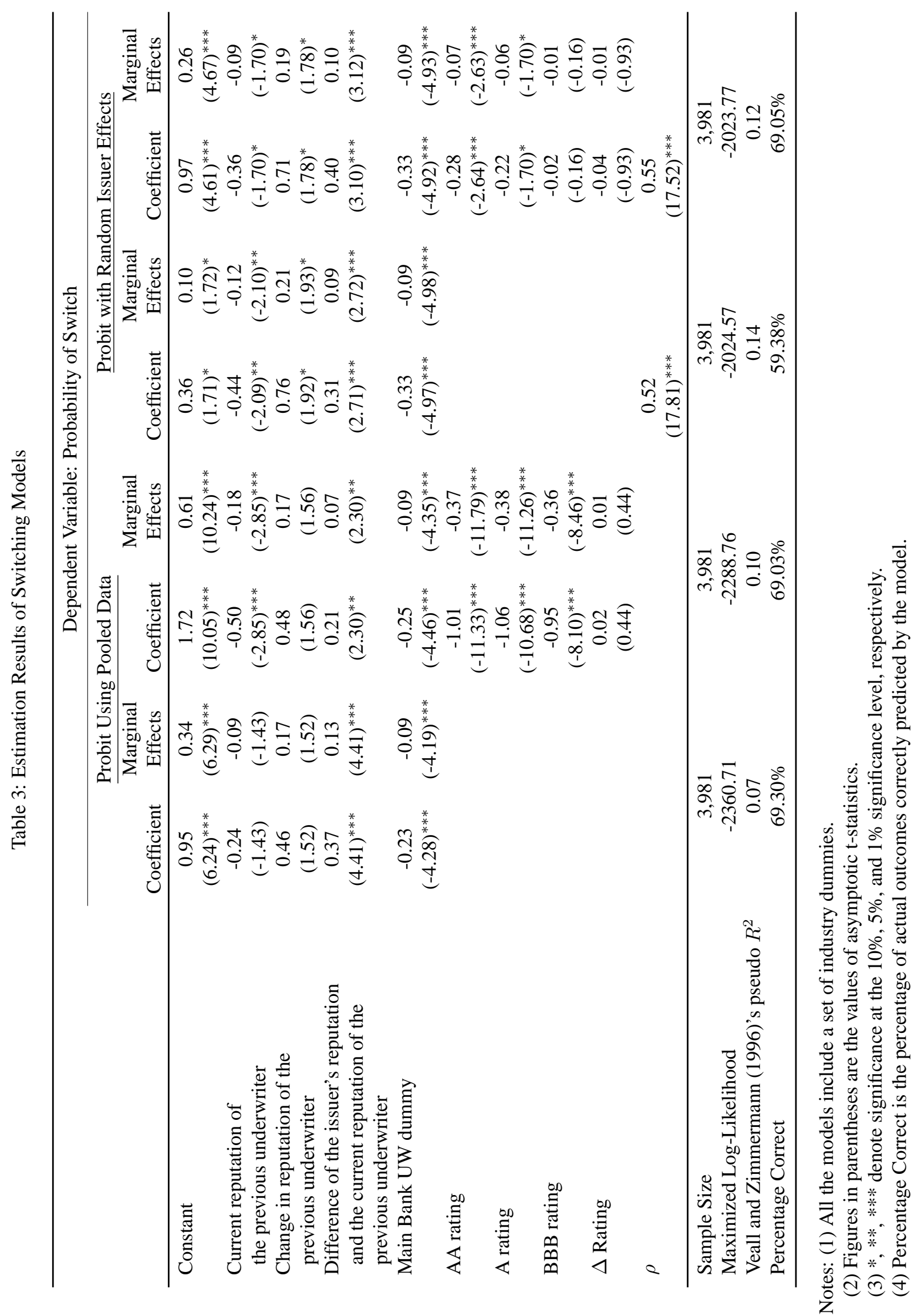

